\title{
"Broken Arabic" and Ideologies of Completeness: Contextualizing the Category of Native and Heritage Speaker in the University Arabic Classroom
}

\author{
Stephanie V. Love \\ Graduate Centre, CUNY, New York, USA
}

Article received 25 January 2016, accepted 16 May 2016, final version 26 May 2016

DOI: http://dx.doi.org/10.5565/rev/jt13.679

\begin{abstract}
Through weekly participant observations and eleven semi-structured interviews conducted with second-generation bilingual students in the Arabic for Native Speakers/Heritage Learners course at one of City University of New York's (CUNY) senior colleges, I investigate the interdiscursive connections between the students' notion of "broken Arabic" and the concept of "incomplete acquisition and/or attrition" (Montrul, 2013) from SLA research on heritage speakers. This paper moves away from the concept of proficiency towards performativity in order to recognize and support diverse repertoires in motion.
\end{abstract}

Keywords: heritage language, Arabic sociolinguistics, incomplete acquisition, linguistic anthropology

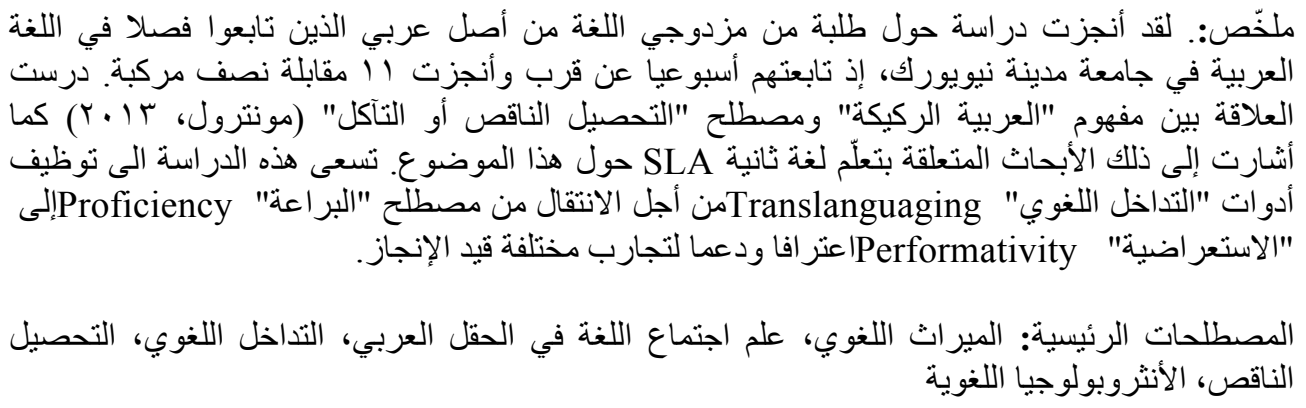

\section{Résumé}

A travers des observations participantes hebdomadaires et onze entretiens semistructurés avec des élèves bilingues de deuxième génération du cours d'arabe pour locuteurs natives/patrimoine des apprenants à City University of New York, (CUNY), j'enquête sur les connexions interdiscursives entre la notion de "l'arabe cassé" et le concept "d'acquisition et / ou d'usure incomplète" (Montrul , 2013) à partir des études de la SLA (Acquisition de la deuxième langue) sur le patrimoine des locuteurs. Cet article se déplace de la notion de compétence vers la performativité afin de reconnaître et de soutenir divers répertoires en mouvement.

Mots-clés: patrimoine linguistique, sociolinguistique arabe, acquisition incomplète, anthropologie linguistique. 


\section{Introduction}

In November of 2015, newspapers around the United States reported that two passengers of Southwest Airlines, Maher Khalil and Anas Ayyad, were pulled aside during the boarding process at Chicago's Midway Airport. ${ }^{1}$ The reason given to these two men-a Philadelphia pizza shop owner and his friend - was that another passenger had overheard them speaking Arabic and became concerned. A similar case was reported in April of 2016 when Khairuldeen Makhzoomi, a student of the University of California, Berkeley and an Iraqi refugee, was pulled off of his flight and questioned by the FBI for speaking with his uncle on the phone in Arabic. ${ }^{2}$ The mere speaking of the Arabic language in the context of the post-9/11 United States-coupled, no doubt, with the racialized bodies of these men - had apparently been the cause of alarm. Arabic, much like many other immigrant languages in the US, has become an icon and emblem of supposedly intractable cultural differences and of the suspicion and fear of linguistic, cultural and religious diversity: that is, "the other within".

It was with these stories in mind that I began to analyze my data from the weekly participant observations and eleven semi-structured interviews I conducted with students in the Arabic for Native Speakers/Heritage Learners course at one of City University of New York's (CUNY) senior colleges. I asked myself: Considering this context of growing xenophobia, Islamophobia and prejudice based on race, religion and linguistic practices, how do secondgeneration students see their relationship to the Arabic language? Under these politicized conditions, in what ways do they consider their Arabic backgrounds to be a valuable resource inside and outside the classroom? From my participant-observation and interview data, I observed that many of the students expressed an uncertainty towards their Arabic speaking competencies, often referring to their practices as "wrong," "inappropriate," "slang" and speaking "broken Arabic". What struck me as significant was the ways in which these students' narratives, in fact, corresponded in some key ways with the emerging body of research on heritage speakers, which often characterizes second-generation language practices in terms of their "interrupted" and "incomplete acquisition" (Montrul, 2013; Schachter, 1990; Bolonyai, 2007; Valdés, 2005) of their first language. How can we conceptualize the similarities between the discourses of "brokenness" emerging from the students' narratives and those of "incomplete acquisition" proposed by SLA researchers? How does knowledge production on heritage learners in the 
academy both reflect and (re)produce ideological claims about "proper" language and its moral and ethical implications in US society? In this sense, the very concept of "incomplete acquisition" found in SLA literature and "broken language" (be it, "broken Arabic," "broken Spanish," or "broken English") in the everyday parlance of my interlocutors confirms the pervasiveness of the normative ideology of monolingualism and its impact on heritage language classrooms in the United States.

In this essay, I aim to situate Arabic heritage students' apparent insecurities and anxieties around the "appropriateness" of their language practices in the university classroom within the larger interdiscursive frame in which language policies and academic knowledge production often unwittingly help support "the erasure of other languages by denying their speakers social capital and resources" (Mendoza-Denton \& Osborne, 2010, p. 115). These ideologies are connected through the semiotic process of iconization or rhematization (Gal, 2005), in which "linguistic features that index social groups or activities appear to be iconic representations of them, as if a linguistic feature somehow depicted a social group's inherent nature or essence" (Irvine \& Gal, 2000, p. 37). In this sense, the "broken" or "incomplete" language practices of second-generation bilinguals are seen as iconic representations of their supposedly problematic deviation from the monoglot standard (Silverstein, 1996), as the example of Maher Khalil, Anas Ayyad and Khairuldeen Makhzoomi at the beginning of this essay demonstrated. As Otheguy (2013) has argued, by classifying them as "heritage" instead of "native" speakers, SLA researchers have been able to brand second generation bilingual speakers as deficient in ways that they would be weary of doing for linguistic practices classified under the label "native" speaker. Yet, on the other hand, other researchers have noted that the notion of "native language" presupposes its existence, that is, that each of us has $a$ native, mother or first language in the singular (Pennycook, 2012). Similarly, as Mendoza-Denton and Osborne (2010, p. 114) have argued, "the very project of defining 'bilingual' as a category ultimately serves to normalize the monoglot standard, and historically this has helped bolster the status of nation-states as bounded and fully controlled entities". It is in these complex socio-linguistic, political and ideological terrains in which I would like to contextualize my study.

Much of the literature on second-generation students in heritage classrooms has focused on how to define these students, that is, who and what is a heritage speaker? Similarly, research 
on heritage Arabic speakers in the US has largely focused on the linguistic characteristics of second-generation students, who, in turn, are distinguished by how they differ from the native speaker norm (Albirini, Benmamoun, \& Saadah 2011; Albirini \& Chakrani 2016). In contrast, I take an anthropological approach that asks the questions: what work does the category of "native" or "heritage" speaker $d o$ ? For whom and with what consequences does this category do its work? These questions significantly differ from the common aim to come up with a universal definition and category of these learners based on certain perceived linguistic characteristics and proficiency. It instead requires researchers to focus on the pragmatic functions of language, that is, it forces us to recognize that language is always embedded in social systems and contexts in which speakers negotiate their position.

In the following sections, I first describe the driving questions and methodology behind this study. Next, I investigate in more detail the interdiscursive connections between the students' notion of "broken Arabic" and the SLA concept of "incomplete acquisition and/or attrition" (Montrul, 2013). Interdiscursivity refers to how any given utterance is always connected to and reflective of past and future discourses that circulate in wider social, political and historical contexts (Bakhtin, 1981; Bauman, 2005). In this essay, I call for a theory and pedagogy of contingency, which takes into account the many different contexts in which students use their language resources. This approach moves away from an overarching concept of proficiency toward a concept of performance in order to teach second-generation speakers in ways that recognize and support their diverse and creative repertoires.

\section{Research Design and Methodology}

This paper draws upon the initial findings from an ongoing research project at the City University of New York (CUNY) on heritage Arabic teaching and learning. The title of the course that I observed was Arabic for Native Speakers/Heritage Learners, which defined native/heritage speakers in its course materials as "students who grew up in an Arabic speaking household" (in the diaspora, not in the Arabic speaking world). While some of the students placed in the class had had some instruction in Arabic literacy (for example, in Saturday Islamic schools), all the students had a functional understanding of oral Arabic and were considered beginners in standard Arabic literacy as assessed by the program's professors. One of the most immediate problems for 
this Arabic course has been the dearth of resources for heritage learners. In fact, Arabic pedagogical materials to-date have not factored in activities in which heritage students can draw upon their rich linguistic resources and backgrounds in vernacular Arabic varieties in order to scaffold their learning of reading and writing in Modern Standard Arabic (MSA).

In collaboration with the professor of this course, I engaged in weekly participant observations in the fall and winter of 2015. As an advanced Arabic student (but a non-heritage learner) and a teaching fellow of anthropology at a different CUNY senior college, I explained to the students that I was observing the classroom with the aim of helping produce new materials for heritage students in collaboration with the course's professor. My ethnographic work included participant-observing classroom activities and engaging in conversations in Arabic with the students about their linguistic experiences inside and outside the classroom. Despite the fact that I was clearly a language learner myself, the students would often ask me clarifying questions about the classroom activities and Arabic grammar and lexicon. While some students in the classroom would confidently answer my questions in Arabic, other students would only respond in English or with very short answers in Arabic. I observed the same situation in interactions between the professor and the students. From these ethnographic observations, an important classroom dynamic became apparent. Many students would often claim that they couldn't speak or understand Modern Standard Arabic (MSA), appearing not to see how their home linguistic backgrounds in their variety of vernacular Arabic could translate into useful knowledge in the classroom. The result was that the students continued throughout the semester to speak mostly in English with one another in the classroom.

With these two ethnographic observations in mind, I conducted 11 semi-structured linguistic oral history interviews with the students on a volunteer basis, each interview running between 20 and 30 minutes. The interviews were conducted on campus, in English and outside of classroom hours. During the interviews, we discussed the students' relationship to the Arabic language, their home language practices, trips to visit relatives in their parents' countries of origin and their impressions of the course. The purpose of the interviews was to get a sense of what Arabic means to the students, why they decided to take the course, and what were some of their psychosocial concerns about speaking Arabic at school and in their lives. The analysis of this paper is based on three important themes that emerged from the interviews. First, most of the 
students interviewed discussed the different contexts in which they speak Arabic (at home, in the classroom, with friends, in the community, etc.), alluding to how their perceptions of how they speak differ in each context. Second, many students discussed their Arabic speaking using negative evaluating terms, such as "broken," "improper" and "bad". Finally, the students described what they saw as significant differences between the standard register of Modern Standard Arabic (MSA) and their home varieties.

The students I interviewed are members of families from a variety of geographical backgrounds and part of the second-generation (either born in the US or coming by the age of 1). Of the 11 students I interviewed, five are of Egyptian origin (Hamid, Zahia, Samia, Ahmed and Amel), three of Lebanese origin (Fatima, Irene and Sarah), one of Moroccan origin (Rabah), one of Tunisian/Iraqi origin (Safia), one of Yemeni origin (Mahmoud), and one of Sudanese origin (Karem). All names are pseudonyms and some identifying information has been changed to protect the privacy of the participants.

\section{The native speaker vs. the heritage speaker: What's in a category?}

Safia, a 25-year old student in the Arabic for Native Speakers/Heritage Learners course, characterized second-generation language practices as such:

I feel like there is a certain level that everyone in this area who grew up with Arabic parents tends to speak...that same level of brokenness, where you start a sentence in English and end it in Arabic, or vice versa.

This characterization of brokenness raises an important question: Who is a native speaker and what is a native language?

Safia's father fled Iraq decades ago, and while working as a sailor on ships throughout the Mediterranean, he met and married Safia's mother, a Tunisian woman. They came to the US in the 1980s, where Safia was born. Safia grew up in and still lives in a city in New Jersey where there is a large Egyptian population. Because of this, Safia linguistically identifies with the Egyptian vernacular, not her father's Iraqi or mother's Tunisian. In fact, she told me, since her father left Iraq as a refugee, he lost contact with his family, and therefore Safia is unsure if she has any Iraqi features in her repertoire since she has never spoken to another Iraqi other than her father in Arabic. Because of the community in which they live, her parents speak with their friends mostly in the Egyptian vernacular and between each other in Egyptian and Iraqi, but 
never in her mother's Tunisian. Despite having spent many summers in Tunisia with her mother's family, Safia denies that she is able to speak the Tunisian vernacular at all. With her parents, Safia reported that they speak mostly in Arabic with some "broken English". Safia emphasized that growing up in a very urban area with many Hispanic and Arabic kids, her mother didn't want her to be placed in ESL so when she was younger, her mother spoke to her in English. While she considers Arabic to be her first language, by Kindergarten, she reported that she spoke English fluently, and her Arabic went to the wayside. She describes her family language practice as such:

With my parents, I speak mostly Arabic. Dialect-wise...it is very broken. It's not like Tunisian-style at all. The only thing is that where we live (in New Jersey), the Arabs that live there...it is a very heavy Egyptian population, and when I was younger, I went to normal public schools but...(my parents) sent me on Saturdays to learn Arabic at a mosque; it was with a whole bunch of Egyptians so I picked up on that dialect more, not $100 \%$, like I don't say the "ga", but it's a mix... When I am at home, (I speak) mostly in Arabic with broken English in-between.

Reflecting the dominance of the Egyptian vernacular throughout the Arabic-speaking world, Safia's case is an interesting example of the ways that Arabic language practices in the diaspora are shaped by features of sociolinguistics, patterns of migration, and hierarchies of language that emerge locally, regionally, and globally.

When thinking about students such as Safia and her complex, variegated repertoire, I question: What would SLA researchers consider to be her native language? Roughly half of the students I interviewed claimed that their Arabic vernacular varieties were their first language, while the other half claimed English to be their first language. Others claimed that both English and their Arabic colloquial variety were their first language. In any case, it is clear from Safia's experience that, in contexts of multilingualism, children often have a composite repertoire from a very early age.

In the emerging field of heritage language research and pedagogy, many scholars have cited Valdés' (2005, p. 412) definition of these students as "raised in a home where a non-English language is spoken", which conforms with the definition provide by the Arabic for Native Speakers/Heritage Learners course of this study. A large portion of the literature on heritage students aims to grapple with, in one way or another, the dilemma of whether or not to define these learners as native speakers. Certainly, in sociolinguistics, the notion of native speaker has been extensively critiqued over the last decades, with some scholars questioning the analytical 
purchase of the category (Cook, 1999; Firth \& Wagner, 1997; Pennycook, 2012). Nevertheless, the notion of native speaker is still widely used in SLA research and language pedagogy.

In this context, the category of "native" is a powerful social fact that is resisted, debated, contested and adopted by speakers in order to make certain social, political and ideological claims. My interviews and classroom observations suggest that students and professors strategically draw upon the label of nativeness at certain moments; while at other times, they reject the label. Rabah, for example, sustained that his native tongue was English even though Moroccan Arabic was the primary language spoken at home during his childhood. During class, he would often refuse to respond to the professor in Arabic, although the professor would often speak to him in Moroccan Arabic. Irene also expressed that while she can understand the Lebanese dialect relatively well, she conflated "Arabic" with MSA, stating that she "can't speak Arabic very well for the most part". Zahia reported to me in an interview that:

...ever since I was younger, I had no real first language, I learned both (Arabic and English) hand in hand at school.

Though Zahia reported being very confident in her Arabic speaking competence, she nevertheless didn't claim Arabic as her first language. What these statements allude to is a significant ambivalence on the part of many students towards their status as "native speakers" of Arabic in the context of this university heritage language program.

Montrul (2013, p. 154), a leading scholar in the field of heritage language pedagogy, has argued that, while a native speaker is difficult to define, "when we see or hear a native speaker we intuitively recognize them as such". Comparing second-generation speakers to what she sees as the "complete and successful outcome of acquisition of a first (or native) language in a (predominantly) monolingual environment" (p. 154), Montrul concludes that because many second-generation speakers' practices fail to reach these intuitive "native" standards due to the processes of "incomplete acquisition and/or attrition" (p. 153), these speakers should be understood as heritage speakers, even when "it is possible to retain native-like ability in some specific areas" (p. 153), such as phonology. In this context, the goal of heritage classrooms should be to aid students in "(reaching) the highest levels of linguistic achievement in their heritage language" (p. 154).

There are at least three problems with Montrul's definition. First, as Dąbrowska (2012) has argued, researchers are starting to question the validity of the notion that all speakers of a 
language share one mental grammar. Dąbrowska found that the common notion that first language speakers eventually converge on one single mental grammar, the acquisition of which is complete by the age of 5, fails to account for the reality of variation in speakers' repertoires. She writes, "Assertions about convergence in L1 acquisition are rarely justified, presumably because they are regarded as self-evident: we can understand one another, so we must have the same grammar. But this is clearly a non sequitur: sharing the same grammar is not essential for successful communication" (Dąbrowska, 2012, p. 4). Second, the supposedly intuitive recognition of a native speaker is never solely based on an objective judgment of another's language practices. To be fair, Montrul (2013) does recognize that the notion of a native speaker is largely a myth though she continues to use the concept. But, she does appear to fail to note that other non-linguistic aspects of a speaker's identity often shape and condition the ways that language practices are perceived by listeners. A speaker's perceived race, name, clothing, immigration status, nationality, etc. can influence the ways that the listener's "intuition" works (Flores \& Rosa, 2015; Hill, 1998). Finally, Montrul's definition also assumes that there is such a thing as an ultimate or target attainment, that is, a moment when language acquisition can be understood as complete.

As Pennycook (2012) has argued, the question of nativeness is rooted in a deceivingly simple question: what does it mean to know a language? In order to answer this question, one must recognize that the notion of linguistic competence is never neutral and that the concept of linguistic proficiency cannot be separated from the socio-political notion of the "legitimate speaker" (Bourdieu, 1977). While many scholars strongly critique the usefulness of the term "native speaker," the discursive power of the concept cannot be ignored. Most importantly for this paper, Pennycook (2012) draws attention to the particular contexts in which someone can pass for a native speaker - a status that one attains but is not necessarily born with-which shows that the category itself is mobile, shifting and performative.

\section{Ideologies of Incompleteness and "Brokenness"}

One particular vexing question for the Arabic for Native Speakers/Heritage Learners course has been how to conceptualize the students' backgrounds in vernacular, regional Arabic ('ammiyya) with the course's goals of reading and writing in Modern Standard Arabic (MSA or 
fuṣhāa). Most of the students I interviewed displayed significant uncertainty regarding the relationship between MSA and their vernacular varieties. In fact, many students reported to me that they speak their vernacular varieties with confident fluency in some contexts (for example, with their parents or in individual meetings with the professor), but display a lack of confidence when they are expected to speak in MSA in the classroom. One student, Mahmoud, whose parents are both from Yemen, shared with me that before this class, he "didn't know fuṣhā existed honestly". He currently works in an Arabic-speaking doctor's office in Brooklyn, which has exposed him to many different vernacular varieties. Yet he believes that his own language practices are very different from the MSA that he is studying in the classroom. Similarly, Sarah, a student from a Lebanese family, said:

I always knew there was fuṣhā but I never really looked into it. And obviously my parents don't speak to me in fuṣhā. (In this class), we are expected to learn in fuṣhā because we need to be uniform, or otherwise everyone would be writing in mușri (the Egyptian dialect) or something like that.

Amel, a student born in Egypt who came to the US at the age of one, said that she sometimes practices fuṣhā at home with her family, but always as a joke. She said that one time her little brother protested when she spoke in MSA at home, saying "That's not Arabic, you're not learning Arabic." Zahia, another student of Egyptian origin, showed the affective and interpersonal weight of this second-generation repertoire. She said:

When I am mad at (my sister), I start speaking to her in Arabic because it sounds madder. I flip flop with her, I can have half a sentence in Arabic and half in English; with my dad it's the same thing. Half English, half Arabic. In a sentence, I can have 4 words in Arabic, and 3 in English, it's a mixture.

Other students also noted that is it common with their family and friends to easily access and engage with the different varieties and registers within their repertoire at any given moment. Considering the great diversity and complexity that constitutes the students' repertoires, what are the implications of comparing second-generation speakers in the diaspora with speakers educated and socialized in the Arabic-speaking world?

In fact, many SLA researchers of heritage language learning have done precisely that (Cook, 1999); by comparing second-generation students to monolingual "native" speakers, this research has adopted the analytical framework referred to as "incomplete acquisition and/or attrition", characterized by the processes of language interference, arrested, flawed or disrupted 
acquisition and the "the erosion, decay, contraction, or obsolescence of a language" (Valdés, 2005, p. 417). Researchers have argued that this incomplete acquisition is brought about by the language shifts that arise from schooling in the dominant societal language. Otheguy (2013) has strongly criticized the notion of "incomplete acquisition" in terms of the linguistic-psychological flaws in its research, arguing that the term should not be used at all. He argues that what these researchers have called incomplete acquisition is instead the product of "normal intergenerational language change accelerated by conditions of language contact" (Otheguy, 2013, p. 1). In fact, socially disfavored varieties of language are often characterized as deviant and deficient. Cabo and Rothman (2012) have also argued that comparing bilinguals to monolinguals is unjustified and that characterizing bilingual practices as incomplete misses the point that they are simply different. Cabo and Rothman (2012, p. 452) write:

The term incomplete is not only imprecise, it is misleading. Since incompleteness is often interpreted as a deficiency, the term is not appropriate when comparative differences can be traced back to contact-induced changes in first generation immigrant input providers to subsequent generations of (heritage speakers).

Yet the comparing of multilingual speakers with monolinguals is precisely what many studies on heritage learners have done. Regarding the term "heritage speaker," Otheguy (2013, p. 12) writes:

The ill-defined term contributes to the unfounded initial legitimacy of the incomplete acquisition hypothesis, for it serves to naturalize the position that heritage speakers, whatever they are, are not native speakers. This removal of second-generation bilinguals from the groups of native speakers makes it possible for linguists to overcome what would otherwise be a reluctance to view anyone's native language in deficit terms. In addition, the terms makes it acceptable to dispense with the common assumption among linguists that, when confronted with unfamiliar items in speakers who have used a language from earliest infancy, what we are witnessing is dialectal differences among natives rather than incompleteness.

This insight has at least two notable implications. First, it calls for a macro-contextualization of the knowledge production in the academy. Second, it emphasizes the ideological work of the notion of "native speaker". In the case of heritage language research, removing the term "native" from the definition of heritage speakers allows researchers to make claims about the inadequateness, deviance, and erroneousness of heritage language, as those who have not acquired the legitimate status of native speaker (Flores \& Rosa, 2015; Firth \& Wagner, 2007).

Here, I argue that the supposed deviance of second-generation language practices as described in SLA literature is interdiscursively connected to the students' representations of a 
part of their repertoire as "broken Arabic". The students I interviewed often expressed shifting views of their language practices within the same discourse - at times reporting that they speak well, and at other times, claiming they could hardly speak at all. The parallel cases of Irene and Sarah demonstrate the ways that students draw on divergent narratives regarding their linguistic backgrounds within the same utterance in order to make certain social and academic claims. Irene's parents emigrated from Lebanon after they were married and shortly before Irene and her five brothers and sisters were born. She told me that at home she doesn't speak much Arabic though her parents speak exclusively in Arabic with each other. Irene reported that she doesn't recall speaking Arabic as a child, but she said:

I can understand it, not formal (fuṣhāa) at all, but speaking for the most part (I can understand).

Yet Irene saw her proficiency in Lebanese Arabic quite differently from the MSA studied in class, giving herself a relatively high self-reported proficiency score (8 out of 10) in her colloquial variety. Sarah, also of Lebanese origin, described the emotional push-and-pull embodied in her relationship to Arabic. Sarah considered Arabic her first language, which is the language she speaks with her grandmother, who she said raised her and who still lives with her. Yet Sarah reports that she speaks mostly in English with her mother, father and four sisters. Like Irene, Sarah considered the Lebanese vernacular she speaks at home to be very different from fuṣh ạ.

Both Sarah and Irene in their interviews made it a point to explain to me that they do not think they belong in the Arabic for Native Speakers/Heritage Learners course. Both students demonstrated resistance to the use of the category of native speaker in describing their relationship to Arabic. Regarding enrolling in this class, Sarah reported that the professor:

...told me to take the heritage speaking one. But I wish I didn't. I feel like more than half the class already knows how to write it and speak it, so I feel like I'm at a disadvantage because I actually don't know how to write it, and I think the class is much more advanced than I am.

Sarah reported that her mother agrees with her. Sarah said:

My mom said, 'this is not at your level, this is way too advanced, how are you going to do well?' I was like, I really don't know I am just going to try my hardest. 
What is interesting about Sarah's narrative is that while she distanced herself from the native speaker category, at other times she referred to her abilities in positive terms. She said:

I know how to speak it well, and in the hospital I translate for people, but I don't know how to write it.

What I want to emphasize here is that students often draw upon the category of native speaker at different moments in order to make specific social claims. The concept of native speaker does particular social and linguistic work, which is always contingent on context. Speakers may in a specific context, such as in the heritage classroom, consider themselves to have "broken" language practices, while in other contexts, such as the home, consider themselves fully competent and fluent. A speaker's perceived performance also depends on the audience.

\section{Conclusion}

Public debates around the social function of bi-/multilingualism draw heavily upon "folk" discourses that say more about the social and political hierarchies, ideologies and economies that structure social relations than the nature of language itself. As Silverstein (1996, p. 301) poignantly writes, "Monoglot Standard is a cultural emblem in our society, it is not a linguistic problem as such that we are dealing with". Language researchers and policymakers are far from immune to this "folk" understanding, at times with serious consequences for second-generation students (Cook, 1999). The circulation of "folk" discourses around the incompleteness of certain language practices (and iconically representing certain types of "incomplete" citizens) have been reinforced and constituted through academic knowledge production. The result can be language pedagogies that unwittingly reproduce the social dynamics of exclusion and inclusion through the categories of "native," "heritage," and "broken" language. Shedding light on the cultural, political and economic (in contrast to linguistic) implications of these debates over bi/multilingualism is central to an analysis of how conscious and unconscious linguistic choices work to position speakers within and resist power structures while leaving space for speakers' agency (Gal, 1987).

In conclusion, there is an expression in Algerian Arabic_- -لسانك ميزانك-which roughly translates to: your language is your balance. For language researchers and social scientists who are tasked with the production of knowledge, we should take this warning to heart. The words we use matter. Yet, this is true perhaps less due to the capacity of words to describe a preexisting 
reality than for the ability of words to bring a concept into existence and transform it into a social fact. The notion of "incomplete acquisition" that has become popular in the emerging field of heritage language research should be understood as embedded in larger sociolinguistic and racioideological discourses that (implicitly) represent second-generation bilinguals as deficient, incomplete citizens. Their perceived dual allegiance to the United States and their countries of origin come to be iconically represented in the fears and suspicion aroused by their allegiance to two languages. As the cases of Maher Khalil, Anas Ayyad and Khairuldeen Makhzoomi at the beginning of the paper suggested, the language ideologies that construe the United States in terms of one language $=$ one nation $=$ one religion $=$ one race continue to have a devastating impact on the lives of multilingual speakers today.

\section{References}

Albirini, A. Benmamoun, E. and Saadah, E. (2011). Grammatical Features of Egyptian and Palestinian Arabic Heritage Speakers Oral Production. Studies in Second Language Acquisition, 33, 273-303. doi: http://dx.doi.org/10.1017/S0272263110000768

Albirini, A., \& Chakrani, B. (2016). Switching codes and registers: An analysis of heritage Arabic speakers' sociolinguistic competence. International Journal of Bilingualism, 1, 23. doi: 10.1177/1367006915626587

Bakhtin, M. (1981). The dialogic imagination. Austin, TX: University of Texas Press.

Bauman, R. (2005). Commentary: Indirect indexicality, identity, and performance. Dialogic observations. Journal of Linguistic Anthropology, 15(1), 145-150. Retrieved at: http://www.jstor.org/stable/43104044

Bolonyai, A. (2007). (In) vulnerable agreement in incomplete bilingual L1 learners. International Journal of Bilingualism, 11(1), 3-23. doi: 10.1177/13670069070110010201

Bourdieu, P. (1977). The economics of linguistic exchanges. Social Science Information: Theory and Methods, 16(6), 645-668. Retrieved at http://web.stanford.edu/ eckert/PDF/Bourdieu1977.pdf

Cabo, D. P. Y., \& Rothman, J. (2012). The (Il) logical problem of heritage speaker bilingualism and incomplete acquisition. Applied Linguistics, 33(4), 450-455. doi: 10.1093/applin/ams037

Cook, V. (1999). Going beyond the native speaker in language teaching. TESOL Quarterly, 33(2), 185-209. doi: 10.2307/3587717

Dąbrowska, E. (2012). Different speakers, different grammars: Individual differences in native language attainment. Linguistic Approaches to Bilingualism, 2(3), 219-253. doi: http://dx.doi.org/10.1075/lab.2.3.01dab

Firth, A., \& Wagner, J. (1997). On discourse, communication, and (some) fundamental concepts in SLA research. Modern Language Journal, 81, 285-300. doi: 10.1111/j.15404781.1997.tb05480.x 
Firth, A. \& Wagner, J. (2007). Second/foreign language learning as a social accomplishment: elaborations on a reconceptualized SLA. The Modern Language Journal, 91 (focus issue): 798-817. doi: 10.1111/j.1540-4781.2007.00670.x

Flores, N., \& Rosa, J. (2015). Undoing appropriateness: Raciolinguistic ideologies and language diversity in education. Harvard Educational Review, 85(2), 149-171. doi: http://dx.doi.org/10.17763/0017-8055.85.2.149

Gal, S. (1987). Codeswitching and Consciousness in the European Periphery. American Ethnologist, 14(4), 637-653. Retrieved at http://www.jstor.org/stable/645318

Gal, S. (2005). Language ideologies compared: metaphors of public/private. Journal of Linguistic Anthropology, 15(1): 23-37. doi:10.1525/jlin.2005.15.1.23

Hill, J. (1998). Language, Race and White Public Space. American Anthropologist New Series, 100(3), 680-689. doi: http://www.jstor.org/stable/682046

Irvine, J. I., \& Gal, S. (2000). Language Ideology and Linguistic Differentiation. In P. V. Kroskrity (Ed.), Regimes of Language (pp. 36-83). Santa Fe, NM: School of American Research Press.

Mendoza-Denton, N., \& Osborne, D. (2010). Two Languages, Two identities? Languages and identities. In C. Llamas \& D. J. L. Watt (Eds.). Language and identities. (pp. 113-122). Edinburgh, Scotland: Edinburgh University Press.

Montrul, S. (2013). How "native" are heritage speakers. Heritage Language Journal, 10(2), 1539. Retrieved at http://www.heritagelanguages.org/ViewPaper.ashx?ID=QQ1Ym3c3HcJiFUj1jM4J1g\%3d $\% 3 \mathrm{~d}$

Otheguy, R. (2013) The linguistic competence of second-generation bilinguals: A critique of 'incomplete acquisition'. Keynote Address, Linguistic Symposium on the Romance Languages. New York City. Retrieved at https://scholar.google.com/scholar?q=The+linguistic + competence + of + secondgeneration+bilinguals $\% 3 \mathrm{~A}+\mathrm{A}+$ critique + of + 'incomplete + acquisition' $\& b \operatorname{tnG}=\& \mathrm{hl}=\mathrm{en} \& \mathrm{as}$ sdt $=0 \% 2 \mathrm{C} 33$

Otheguy, R., García, O., \& Reid, W. (2015). Clarifying translanguaging and deconstructing named languages: A perspective from linguistics. Applied Linguistics Review, 6(3), 281 307. doi: 10.1515/applirev-2015-0014

Pennycook, A. (2012). Language and mobility: Unexpected places. Bristol, UK: Multilingual matters.

Schachter, J. (1990). On the issue of completeness in second language acquisition. Second Language Research, 6(2), 93-124. doi: 10.1177/026765839000600201

Silverstein, M. (1996). Monoglot 'standard' in America: Standardization and metaphors of linguistic hegemony. In D. Brenneis \& R. K. Macaulay (Eds.), The matrix of language: Contemporary linguistic anthropology. Boulder, CO: Westview Press.

Valdés, G. (2005). Bilingualism, heritage language learners, and SLA research: Opportunities lost or seized? The Modern Language Journal, 89(3), 410-426. doi: 10.1111/j.15404781.2005.00314.x

Author information: Stephanie V. Love is a Ph.D. student in linguistic anthropology at the City University of New York (CUNY) Graduate Center and a teaching fellow at Brooklyn College, CUNY. Her research interests include diaspora studies in the Mediterranean, heteroglossia, Arabic sociolinguistics and language ideologies, bilingual and adult education, and ethnography of death and burial in Algeria. She has published articles in the International 
Journal of Multicultural Education and Current Issues in Language Planning. She has recently co-edited a volume on the Italian author Elena Ferrante, which will be published by Palgrave McMillian in the fall of 2016.

Email: slove@gradcenter.cuny.edu

\section{Notes}

${ }^{1}$ See http://www.theguardian.com/us-news/2015/nov/21/southwest-airlines-muslim-middle-eastern-passengers

${ }^{2}$ See http://www.theguardian.com/commentisfree/2016/apr/19/why-speaking-arabic-america-feels-like-crime

To cite this article:

Love, S.V. (2016). Broken Arabic" and ideologies of completeness: Contextualizing the category of native and heritage speaker in the university Arabic classroom. Bellaterra Journal of Teaching \& Learning Language \& Literature, 9(2), 78-93. DOI: http://dx.doi.org/10.5565/rev/jt13.679 